to special scientific knowledge is wide acquaintance with general science. More and more dental students are nowadays going in for degrees in arts, in medicine, and in surgery; and it seems at least doubtful if the aspirations of this class of candidate would be at all satisfied by the suggested higher dental diploma.

I am, Sirs, yours obediently,

Wimpole-street, Sept. 26th, 1891. HENRY SEWILL.

\section{CHLOROFORM SYNCOPE.}

\section{To the Editors of THE LANCET.}

SIRS, - I am much obliged to Dr. Kirk for pointing out what is a distinct omission in the account of my case of chloroform syncope, and hope you will allow me a few lines to supply the deficiency. The administration of chloroform was not discontinued until after the pupils dilated and the respiration had all but stopped. I may say that the whole occurrence did not take more than two minutes at the most from Mr. Sankey's first remark till the cessation of respiration. There were no interruptions to the administratiou, except that at first the patient herself removed the mask after a breath or two, being, as I explained, very excitable. The amount of chloroform used may seem large, but she took some little time before it began to affect her, holding her breath and talking, and I followed my usual practice of keeping up a continuous stream of chloroform vapour, believing as I do that the proper method of giving chloroform is to administer it freely and fully, and, in fact, to push it until anæesthesia is complete-a view which, I take it, fully corresponds with Dr. Kirk's opinions. My experience of chloroform administration, amounting now to about a thousand cases, leads me to think that three drachms of chloroform, even with Junker's inhaler, is not an extraordinary quantity to use to produce anæsthesia with a patient who, as in this case, was highly nervous and excitable. I am, Sirs, yours faithfully,

Banbury-road, Oxford, Sept. 28th, 1891. EDWARD Rice.

\section{INSTRUCTION IN HYGIENE.} To the Editors of THE LANCET.

SIRS, - It has been arranged to hold a preliminary meeting to secure the efficient recognition of hygtene as a compulsory subject in the curriculum for the ordinary medical degrees. The suggested resolutions include one to that effect, and the presentation of a memorial to the General Medical Council, with such other measures as may be deemed advisable. I should be glad to hear from gentlemen in the profession interested in the advance of sanitary science who may be unable to attend.

I am, Sirs, yours obediently,

Antony Roche, M.R.C.P.I., Hon. Secretary.

Harcourt-street, Dublin, Sept. 29th, 1891.

\section{THE CONGRESS OF GERMAN NATURALISTS AND MEDICAL MEN.}

(From our Berlin Correspondent.)

THE sixty-fourth annual Congress of German Naturalists and Medical Men was opened in Halle on Sept. 21st, Professor His of Leipsic in the chair. The large hall was densely crowded, and many famous men of science were present. After a short speech from the chairman, Professor Knoblanch of Halle spoke. He referred to the meetings held in Leipsic in 1822 and in Halle in 1823, at the former of which only twenty persons were present; named the men who spoke on those occasions, and their themes, and celebrated the enormous strides science had taken since then. After speeches of welcome had been delivered by several high governmental officials, and the rector of Halle University, Professor Nothnagel of Vienna spoke on the limits of the art of healing. Illness, he said, is life under altered conditions; this dictum of Virchow's leads to the question, What is healing? The answer is: the bringing back of the altered tissues and of the disturbed functions to the normal state, the re-establishment of the healthy relation between the tasks and the performances of the organism. The possibilities of healing not only are limited, but will probably always remain so in many cases. Real healing is never effected by internal therapeutic means, but always by the organism itself. The physician is only the servant of Nature, not her master. He can support her in her conflict with the enemy, and take care that she be not hindered. But the less possible cure is seen to be, the more important becomes prevention. In the few cases in which internal remedies are applied with success against certain maladies, it is probable that success is due to the removal of the causes of the disease. In malaria, for instance, quinine cannot restore the tissues to their normal state ; but it seems to render the plasmodia, the probable germs of the disease, harmless, so that the process of self-healing may go on undisturbed. But, though the healing of disease is confined to very narrow limits, and though bounds are set even to the possibility of its prevention, a wide field remains open to the healer in the combating of symptoms, and thus alleviating the patient's sufferings, preserving his power of work, and not rarely even giving the organism time and rest to heal itself. After surveying the long series of remedies introduced in recent times, the speaker expressed the hope that the healing art will go on progressing within the limits of natural law.

In the second general meeting one of the speakers was Professor Ebstein of Gottingen, who treated his theme-the Art of Prolonging Human Life-in an interesting manner, without saying any thing very novel.

In the third and last public sitting Professor Ackermann of Halle spoke on Edward Jenner and the Question of Immunity. He gave a sketch of Jenner's life, and went into the history of vaccination. After all the hypotheses that have been brought forward, the explanation of the extraordinary fact of immunity, which is no longer confined to vaccination for small-pox, still remains one of the great problems of science. The speaker concluded with the remark that the 24th of May, 1896, the hundredth anniversary of the day on which Jenner performed vaccination for the first time, might well be celebrated as a day of joyful and grateful remembrance all over the world.

A disinfecting apparatus, invented by Dr. Hermann Rohrbeck of Berlin, was exhibited in the garden of the medical clinic, and attracted much attention. Its purpose is to render the flesh of locally tuberculous animals and other objectionable meat fit for human food, by subjecting it in all its parts, and within a short time, to a temperature of at least $100^{\circ} \mathrm{C}$. It differs from the usual disinfectors in two respects : it lets no "dry" steam in, and it leaves no remnants of air in the interior of the disinfected articles. The latter purpose is attained by condensing the steam with which the apparatus is filled, by washing over a double cover adjnsted in the boiler, a process which can be repeated ad libitum

In the Section of Hygiene, Professor Lehmann of Würzburg made a highly important and astounding communication regarding the pollution of the meal of which the coarse rye-bread eaten on the Lower Rhine is baked. In the course of investigations concerning the value of a new method of husking corn, he had hit upon instances of such pollution. He procured eighty samples of flour and bread, such as are used and sold by small millers and bakers there. All of them were largely, some to an incredible extent, polluted, not only with earth, excrement of mice, and other disgusting but not exactly noxions things, but also with blighted corn, darnel, cockle, and other poisonous seeds. None of the samples were free of cockle, and in some the quantity of this ingredient exceeded 1 per cent., so that 100 grammes only of such bread would suffice to produce a poisonous effect. How many cases of gastric catarrh and other diseases, which had been attributed to every imaginable cause, might be due to nothing else than the eating of such bread? The speaker referred to the Adulteration Act, which carefully enumerates and threatens with punishment all the possible pollutions of cinnamon, pepper, and other agreeable but comparatively dispensable things, while it leaves the staple of life unmentioned. It was the duty of the police, he said, to keep a sharp eye on this nuisance, which seemed to be confined to North-west Germany, and to prosecute offenders with all rigour.

In the Section of Dentistry Professor Hollaender of Halle reported on a new anæsthetic called pental, which does not produce total unconsciousness, but only a kind of hypnosis.

In the Section of Internal Medicine Dr. P. Guttmann of Berlin reported on two typical cases of malaria which had 